\title{
Meridional shifts of the Atlantic intertropical convergence zone since the Last Glacial Maximum
}

\author{
Jennifer A. Arbuszewski ${ }^{1 \star}$, Peter B. deMenocal ${ }^{2}$, Caroline Cléroux ${ }^{3}$, Louisa Bradtmiller ${ }^{4}$ \\ and Alan Mix ${ }^{5}$
}

The intertropical convergence zone is a near-equatorial band of intense rainfall and convection. Over the modern Atlantic Ocean, its annual average position ${ }^{1}$ is approximately $5^{\circ} \mathrm{N}$, and it is associated with low sea surface salinity and high surface temperatures. This average position has varied since the Last Glacial Maximum, in response to changing climate boundary conditions $^{2-15}$. The nature of this variation is less clear, with suggestions that the intertropical convergence zone migrated north-south away from the colder hemisphere $e^{10-15}$ or that it contracted and expanded symmetrically around its present position ${ }^{2}$. Here we use paired $\mathrm{Mg} / \mathrm{Ca}$ and $\delta^{18} \mathrm{O}$ measurements of planktonic foraminifera for a transect of ocean sediment cores to reconstruct past changes in tropical surface ocean temperature and salinity in the Atlantic Ocean over the past 25,000 years. We show that the low-salinity, high-temperature surface waters associated with the intertropical convergence zone migrated southward of their present position during the Last Glacial Maximum, when the Northern Hemisphere cooled, and northward during the warmer early Holocene, by about $\pm 7^{\circ}$ of latitude. Our evidence suggests that the intertropical convergence zone moved latitudinally over the ocean, rather than expanding or contracting. We conclude that the marine intertropical convergence zone has migrated significantly away from its present position owing to external climate forcing during the past 25,000 years.

The intertropical convergence zone (ITCZ) resides in the Northern Hemisphere for much of the year but varies by season and region, shifting into the summer hemisphere with exceptional northward monsoonal penetrations over the subtropical continental land masses ${ }^{10}$. Historical interannual variability of the mean position of the marine ITCZ is of the order of $\pm 2^{\circ}$ and has been linked to interannualmultidecadal oscillations that have significant impacts on tropical communities $^{16}$.

Here we assess whether the historical range of Atlantic ITCZ variability is a limit, or whether much larger variations may have occurred. We focus on open-ocean sediment core locations to evaluate latitudinal shifts of the marine Atlantic ITCZ. The arcing seasonal trajectory of the southeast trade winds across the Equator, associated with the North African summer monsoon, causes surface divergence and upwelling, leading to cooler sea surface temperature (SSTs; $23-24^{\circ} \mathrm{C}$ ) in the Gulf of Guinea and establishing a zonal SST gradient $\left(2-3^{\circ} \mathrm{C}\right)$ with a subsurface thermocline sloping steeply to the west. The ITCZ is bounded to the north and south by the high-salinity subtropical gyres where the poleward limbs of the Hadley circulation descend and excess evaporation occurs.

We use the low-salinity signature of the marine ITCZ to identify shifts in its position from the Last Glacial Maximum (LGM) to the present (the past 25,000 years (25 kyr)) using data from an open-ocean transect of sediment cores. We compare these data to published continental and marine palaeohydrological records spanning $20^{\circ} \mathrm{N}$ to $15^{\circ} \mathrm{S}$ to develop a more comprehensive picture of ITCZ migrations. Sediment cores VM25-59, VM30-40, RC24-08 and RC24-11 lay along the flanks of the Mid-Atlantic Ridge in the equatorial Atlantic (Fig. 1). These sites have similar bottomwater $\Delta \mathrm{CO}_{3}{ }^{2-}$ values today $\left(\sim 12-22 \mu \mathrm{mol} \mathrm{kg}{ }^{-1}\right.$; Supplementary Information), with no significant meridional or zonal biases. This sample selection minimizes potential spatial biases due to changes in post-depositional shell dissolution resulting from deep-water circulation changes (Supplementary Information). We use paired $\mathrm{Mg} / \mathrm{Ca}$ ratios and $\delta^{18} \mathrm{O}$ measurements on the surface-dwelling foraminifers Globigerinoides ruber (white) and Globigerinoides sacculifer to reconstruct SST, $\delta^{18} \mathrm{O}_{\text {seawater }}$ (a proxy for surface salinity) and salinity (Supplementary Figs S1 and S2, Text and Tables S1 and S2; ref. 17) ${ }^{18,19}$. Core-top $\delta^{18} \mathrm{O}$ and $\mathrm{Mg} / \mathrm{Ca}$ calibration studies indicate that these taxa record mean annual surface ocean mixed layer $(0-50 \mathrm{~m})$ conditions in the tropics ${ }^{19,20}$. Local $\delta^{18} \mathrm{O}_{\text {seawater }}$ changes due to variations in surface salinity (and surface salinity estimates) were isolated by first removing the global $\delta^{18} \mathrm{O}_{\text {seawater }}$ component due to ice volume changes ${ }^{21}$.

We compared two methods of estimating palaeotemperature from shell Mg/Ca values, both of which indicate similar magnitudes of average LGM-late Holocene reconstructed SST changes. The depth-corrected Atlantic Basin G. ruber Mg/Ca palaeotemperature calibration of ref. 18 shows that equatorial Atlantic SSTs cooled by $\sim 1-5^{\circ} \mathrm{C}$ relative to average late Holocene core-top estimates to a zonally uniform $23-24^{\circ} \mathrm{C}$ during the LGM, with an early Holocene establishment of a near-modern zonal SST gradient (Fig. 2). The LGM SST estimates from a new multivariate palaeotemperature equation that includes shell $\mathrm{Mg} / \mathrm{Ca}, \delta^{18} \mathrm{O}$ and corrections for bottom-water $\Delta \mathrm{CO}_{3}{ }^{2-}$ suggest that SSTs were on average $\sim 1.5-4.5^{\circ} \mathrm{C}$ cooler than late Holocene core-top SST estimates, with a more gradual deglacial warming trend and later establishment of the modern zonal SST gradient ${ }^{19}$ (see Supplementary Information). Both methods yield late Holocene SSTs within error of the modern mean annual SST (WOA09) and suggest coherent zonal LGM cooling, implying invigorated wind-driven tropical Atlantic upwelling. This view is supported by higher LGM Th-normalized

\footnotetext{
${ }^{1}$ Woods Hole Oceanographic Institution, 111A Clark (MS \#23), 266 Woods Hole, Massachusetts 02543-1050, USA, ${ }^{2}$ Lamont-Doherty Earth Observatory of Columbia University, 211 Geosciences, 61 Route 9W, Palisades, New York 10964, USA, ${ }^{3}$ NIOZ Royal Netherlands Institute for Sea Research, Department of Marine Geology, Den Landsdiep 4, Burg, The Netherlands, ${ }^{4}$ Olin-Rice Science Center 249d, 1600 Grand Avenue, St Paul, Minnesota 55105, USA,

${ }^{5}$ College of Earth, Ocean, and Atmospheric Sciences, Oregon State University, Burt 246, Corvallis, Oregon 97331-5503, USA.

*e-mail: jarbuszewski@whoi.edu
} 


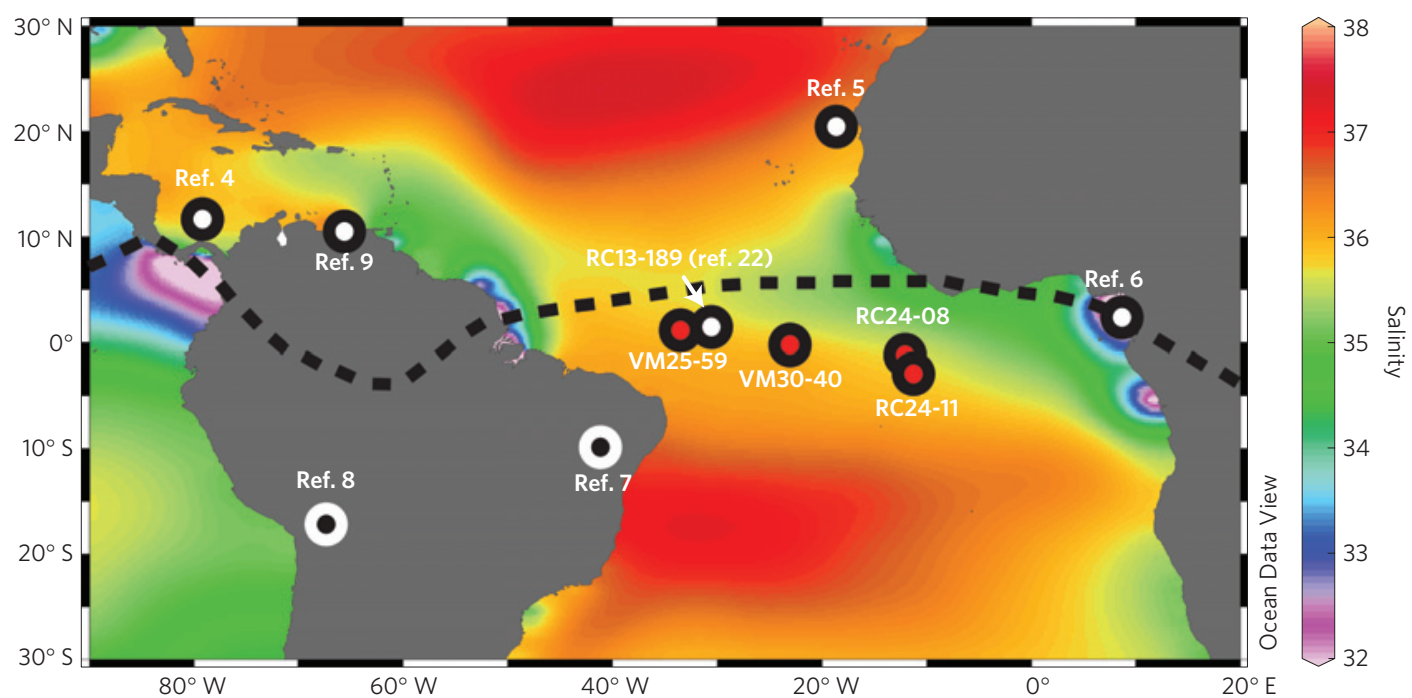

Figure 1 | Map of core locations and approximate modern mean annual ITCZ location. Locations of cores RC24-11, RC24-08, VM30-40 and VM25-59 (red dots), of previously published palaeohydrological records (white dots with a black border for oceanic sites and black dots with a white border for terrestrial sites) and of biogenic opal flux records (represented by red dots for RC24-07 and VM30-40, as the sites are the same as ours; RC13-189 is represented by white dots with a black border; ref. 22). The approximate mean annual position of the ITCZ is shown as the dashed line and is indicated by the low-salinity band north of the Equator.

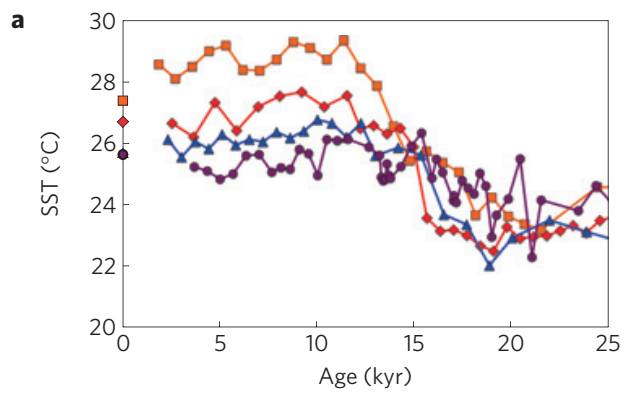

$\rightarrow$ Western Atlantic (VM25-59/RC13-189)

$\diamond$ Central Atlantic (VM30-40)

- Southeast Atlantic (RC24-11)

- Eastern Atlantic (RC24-08/RC24-07)

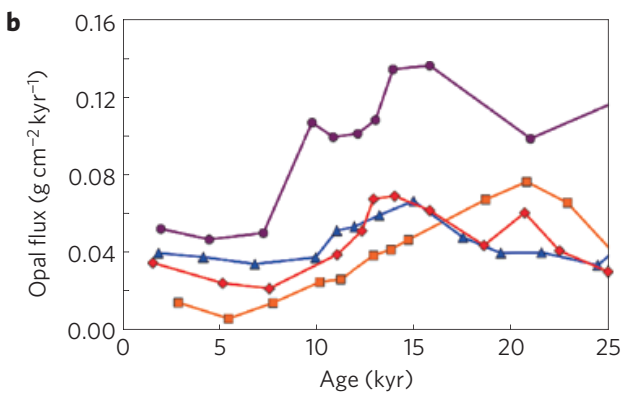

Ref. 18 SST error $\left(\sim 1.2^{\circ} \mathrm{C}\right)$

Figure 2 | SST and opal records since the LGM. a, SST (depth-corrected Atlantic Basin equation of ref. 18). b, Opal flux records (ref. 22). Modern mean annual SST values (WOA09) are shown by symbols on the $y$ axis with seasonal ranges as follows: RC24-08 and RC24-11: $23.3-28.2^{\circ} \mathrm{C}, \mathrm{VM} 30-40$ : 25.5-28. ${ }^{\circ} \mathrm{C}$, and $\mathrm{VM} 25-59: 26.8-28.0^{\circ} \mathrm{C}$. The increased opal flux during the LGM at RC24-07 is taken as an indication of enhanced upwelling in the eastern equatorial Atlantic. Uncertainty bars reflect the calibration error associated with the SST calculation and are equal to $1.2^{\circ} \mathrm{C}$ (ref. 18 ).

opal and organic carbon fluxes observed in several equatorial Atlantic cores, including RC24-08 (Figs 1 and 2) 22,23 .

Rainfall changes associated with past ITCZ shifts influence surface ocean salinities, which are set by the local atmospheric evaporation-precipitation balance (Fig. 1). Here, we provide two estimates of surface ocean salinity to track the low-salinity fingerprint of the marine ITCZ. The first calculates local $\delta^{18} \mathrm{O}_{\text {seawater }}$ by solving the oxygen isotope palaeotemperature equation ${ }^{24}$ using $\mathrm{Mg} / \mathrm{Ca}$-derived SSTs (ref. 18). The second approach calculates surface ocean salinity using an Atlantic Basin multivariate calibration equation ${ }^{19}$ constrained by paired ice-volume-corrected shell $\delta^{18} \mathrm{O}$ and $\mathrm{Mg} / \mathrm{Ca}$ values. A caveat to this second approach is that a constant salinity- $\delta^{18} \mathrm{O}_{\text {seawater }}$ relationship is assumed, which was almost certainly not true in the past ${ }^{25}$. Nevertheless, both approaches yield qualitatively similar results, indicating that our conclusions are robust and independent of calibration method (Fig. 3).

The local $\delta^{18} \mathrm{O}_{\text {seawater }}$ and salinity estimates document large, persistent shifts in the evaporation-precipitation balance over the open Atlantic Ocean that exceed historical ranges, suggesting significant displacements of the marine ITCZ over the past $25 \mathrm{kyr}$. Our open-ocean, equatorial core sites (spanning $1.4^{\circ} \mathrm{N}$ to $2.2^{\circ} \mathrm{S}$, south of the modern mean ITCZ position) document shifts to slightly fresher conditions during the LGM and much more saline conditions during the early Holocene (Fig. 3). The northwestern cores consistently show the largest salinity variability. All cores indicate a freshening during the LGM to salinities within or nearly equivalent to the fingerprint of the modern ITCZ (salinities $\sim 35.4-35.8, \delta^{18} \mathrm{O}_{\text {seawater }} \sim 0.74-0.83 \%$ based on modern values $)^{26}$.

We compare our open-ocean data set with published records spanning $20^{\circ} \mathrm{N}$ to $15^{\circ} \mathrm{S}$ to constrain larger-scale Atlantic region palaeohydrological variations (Figs 1 and 3). These records collectively document a southward shift of the ITCZ during the LGM and the Younger Dryas (where resolved). Records north of the modern ITCZ indicate drier/more saline conditions, whereas proxy records south of the modern ITCZ indicate more humid/fresher conditions (Fig. 3). This is evidenced by the increased local $\delta^{18} \mathrm{O}_{\text {seawater values }}$ (high salinity) at Caribbean core VM19-122 (12 $\mathrm{N}$; ref. 4) and reduced Niger River discharge from subtropical Northwest Africa 


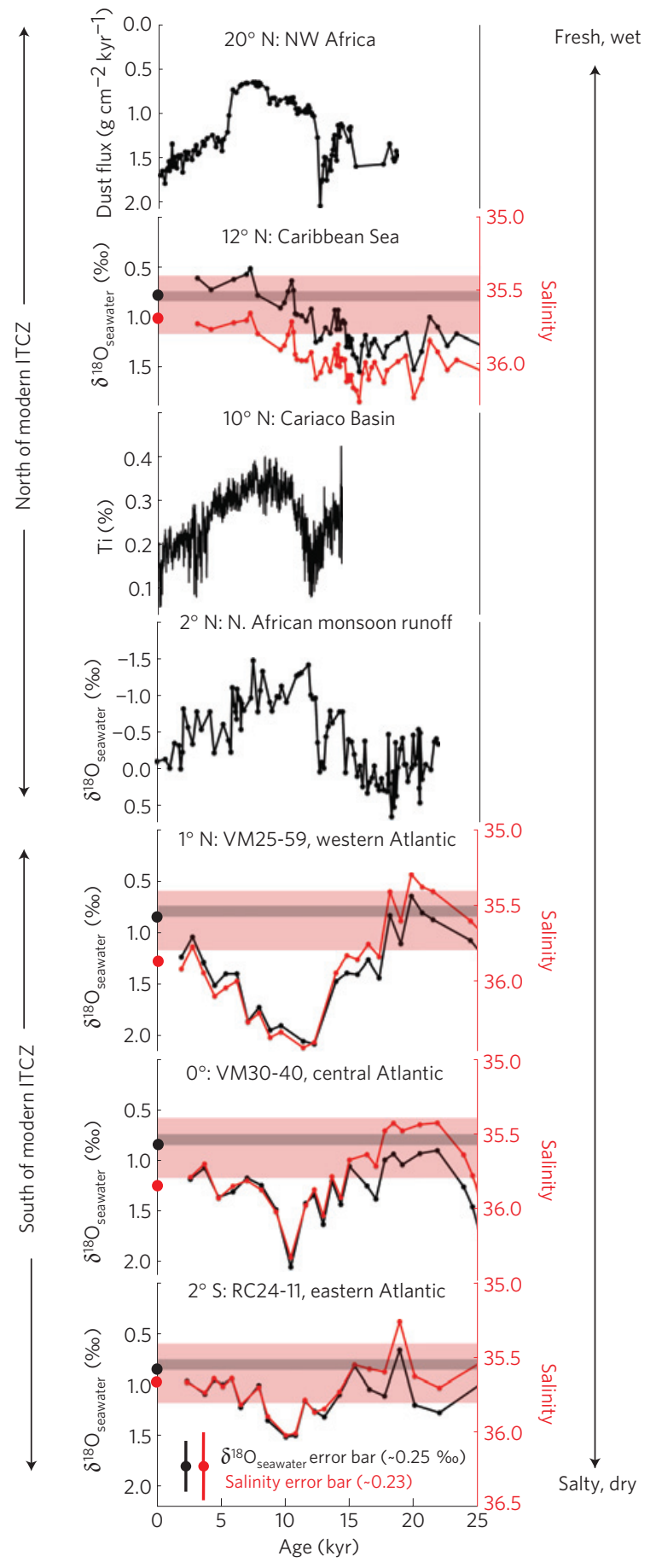

Figure 3 | Palaeohydrological records arranged by location. Wetter and fresher conditions plotted towards the top. From top to bottom: North African dust flux ${ }^{5}$, Caribbean $\delta^{18} \mathrm{O}_{\text {seawater }}$ (ref. 4), Cariaco Basin Ti concentrations ${ }^{9}, \delta^{18} \mathrm{O}_{\text {seawater }}$ reflecting North African monsoonal runoff ${ }^{6}$,

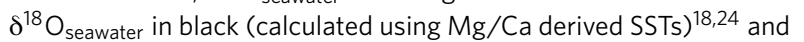
surface salinity in red (new multivariate equation based on paired shell $\delta^{18} \mathrm{O}$ and $\mathrm{Mg} / \mathrm{Ca}$ ) from VM25-59, VM30-40 and RC24-11. Grey (red) bars represent the $\delta^{18} \mathrm{O}_{\text {seawater }}$ (salinity) fingerprint of the modern ITCZ; black (red) circles represent modern mean annual $\delta^{18} \mathrm{O}_{\text {seawater }}$ (salinity) (ref. 26 WOA09). Uncertainty bars represent calibration effects for $\delta^{18} \mathrm{O}_{\text {seawater }}$ $(0.25 \%)$ and salinity $(0.23)$.

recorded in a Gulf of Guinea core $\left(20^{\circ}-5^{\circ} \mathrm{N} \text { drainage basin }\right)^{6}$. These intervals are represented by high Th-normalized dust fluxes off northwest Africa $\left(20^{\circ} \mathrm{N}\right)$, indicating enhanced continental aridity ${ }^{5}$.
South of the modern ITCZ, our surface salinity proxy records are antiphased with those from the north, indicating moderately fresher conditions during the LGM relative to core-top values (Fig. 3). Enhanced speleothem growth in lowland Brazil $\left(\sim 10^{\circ} \mathrm{S}\right)$ and high water levels at Lake Titicaca in Peru $\left(15^{\circ} \mathrm{S}\right)$ also indicate the southward displacement of the rain belt ${ }^{7,8}$. This evidence suggests that the marine ITCZ was displaced at least about $7^{\circ}$ southwards during the LGM and impacted open-ocean salinity gradients with a spatially coherent, meridional signature between $12^{\circ} \mathrm{N}$ and $2^{\circ} \mathrm{S}$.

During the early Holocene when large boreal ice sheets had retreated and orbital precession established enhanced summer insolation and warming in the Northern Hemisphere, there was a northward shift of the Atlantic ITCZ and African monsoonal rain belt. Palaeohydrological proxy records from the northern subtropics document the establishment of more humid conditions on land and lower surface ocean salinities (Fig. 3). This is indicated in the Caribbean by lower local $\delta^{18} \mathrm{O}_{\text {seawater values }}{ }^{16}$ as well as increased river runoff (higher Ti) to the Cariaco Basin ${ }^{20}$ (Figs 1 and 3). Off northwest Africa, low dust fluxes and enhanced Niger River runoff reflect the establishment of wetter conditions over North Africa associated with the African Humid Period ${ }^{5,6}$ (Figs 1 and 3). South of the modern ITCZ, we again see an antiphased signal compared with sites north of the modern ITCZ. Our open-ocean local $\delta^{18} \mathrm{O}_{\text {seawater }} /$ salinity records exhibit the most saline values of the entire study interval (Fig. 3), indicating a northward shift of ITCZ-embedded rainfall away from these locations and the northward advance of the higher-salinity southern subtropical gyre waters. Speleothem growth had halted in lowland Brazil caves, and South American lake levels were low, indicating dry continental conditions ${ }^{7,8}$.

Our results provide the meridional compilation of terrestrial and marine palaeohydrologic data constraining the timing and magnitude of past ITCZ excursions since the LGM. These records collectively provide support for a synchronized southward migration of the ITCZ during the LGM, and northward during the early Holocene. The marine core data, in particular, indicate that these ITCZ swings were persistent enough to have been recorded by marine fauna that record seasonal to mean annual conditions. The meridional reach of these excursions was nominally $\pm 7^{\circ}$ of latitude away from the present ITCZ location in the tropical Atlantic. Such cross-equatorial swings in the mean position of the marine ITCZ have been inferred also for several past glacial-interglacial

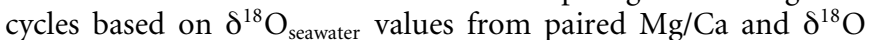
measurements at ODP Site 999A in the western Caribbean (north of the modern ITCZ) and ODP Site 806B in the western tropical Pacific (south of the modern ITCZ; ref. 3).

Climate modelling studies suggest that, dynamically, a large meridional shift in the mean annual position of the ITCZ is difficult to maintain even under variable orbital insolation forcing ${ }^{27}$. Given that each foraminiferal sample represents a finite population of shells accumulated over hundreds years and that surface productivity fluxes are seasonally biased, the observed variability in our data could reflect either large seasonal shifts of the marine ITCZ or shifts in the mean position, and accompanying changes in the basin-scale evaporation-precipitation. Either interpretation requires a southward migration of excess precipitation to at least $2^{\circ} \mathrm{S}$ during the LGM (that is, $7^{\circ}$ south of its present position near $\left.5^{\circ} \mathrm{N}\right)$. We observe a significant northward shift in excess precipitation that when coupled with previously published data is suggestive of a migration to at least the latitudes of the Cariaco Basin $\left(10^{\circ} \mathrm{N}\right.$; ref. 9$)$ and Caribbean Sea $\left(12^{\circ} \mathrm{N}\right.$; ref. 4$)$ during the early-mid Holocene (Fig. 3).

A recent compilation of plant wax biomolecular carbon isotopic data along the margins of western Africa $\left(20^{\circ} \mathrm{N}-17^{\circ} \mathrm{S}\right)$ suggests an alternative view of tropical Atlantic rain belt variability since the last glacial period ${ }^{2}$. Tracking past meridional shifts in 
the African savanna-rainforest boundaries in offshore marine sediment cores, these authors have suggested a symmetrical equatorward contraction of precipitation during the LGM and Heinrich Stadial 1 and symmetrical poleward expansion during the early Holocene ${ }^{2}$. Our transect provides new constraints and supports coherent, meridional migrations of the tropical rain belt away from its present position over the past $25 \mathrm{kyr}$, as expected from orbital theory (ref. 28 and others). Moreover, the marine $\delta^{18} \mathrm{O}_{\text {seawater }}$ data document the surface salinity signatures of these migrations, which are less susceptible to the strongly seasonal biases inherent to some terrestrial palaeoclimate archives. Our results may be reconciled with the study of ref. 2 by echoing its conclusion that the model of uniform latitudinal ITCZ shifts may not be applicable globally. Some observed African climate and vegetation changes respond to complex regional climate controls ${ }^{29}$. We do not rule out expansions/contractions of the African rain belt, but rather suggest that it is not the sole mechanism for explaining the observed hydrological signals across the Atlantic Basin, which clearly document coherent meridional shifts.

Our results strengthen the view offered by palaeoclimate data and climate modelling studies that the marine ITCZ is exceptionally sensitive to high- and low-latitude climate forcings. During the LGM, this manifests as a southward migration in response to high-latitude cooling, ice cover, and reductions in thermohaline circulation $^{10,13,14}$. Conversely in the early Holocene, warming of northern subtropical continental land masses invigorated the summer monsoon, and drew the ITCZ northward (for example, refs 11,12,15). These seasonal and mean annual excursions of the position of the marine Atlantic ITCZ since the LGM impacted the evaporation-precipitation balance of open-ocean core locations at least $\pm 7^{\circ}$ of latitude away from the modern mean position.

Received 5 April 2013; accepted 28 August 2013; published online 13 October 2013

\section{References}

1. Philander, S. G. H. et al. Why the ITCZ is mostly north of the equator. J. Clim. 9, 2958-2972 (1996).

2. Collins, J. A. et al. Interhemispheric symmetry of the tropical African rainbelt over the past 23,000 years. Nature Geosci. 4, 42-45 (2010).

3. Schmidt, M. W. \& Spero, H. J. Meridional shifts in the marine ITCZ and the tropical hydrologic cycle over the last three glacial cycles. Paleoceanography $\mathbf{2 6}$, PA1206 (2011)

4. Schmidt, M. W., Spero, H. J. \& Lea, D. W. Links between salinity variation in the Caribbean and North Atlantic thermohaline circulation. Nature 428, 160-163 (2004).

5. Adkins, J., deMenocal, P. \& Eshel, G. The 'African Humid Period' and the record of marine upwelling from excess ${ }^{230} \mathrm{Th}$ in ODP Hole 658C. Paleoceanography 21, PA4203 (2006).

6. Weldeab, S., Schneider, R. R., Kölling, M. \& Wefer, G. Holocene African droughts relate to eastern equatorial Atlantic cooling. Geology 33, 981-984 (2005).

7. Wang, X. et al. Wet periods in northeast Brazil over the past $210 \mathrm{kyr}$ linked to distant climate anomalies. Nature 432, 740-743 (2004).

8. Baker, P. et al. The history of South American tropical precipitation for the past 25,000 years. Science 291, 640-643 (2001).

9. Haug, G. H., Hughen, K. A., Sigman, D. M., Peterson, L. C. \& Rohl, U. Southward migration of the intertropical convergence zone through the Holocene. Science 293, 1304-1308 (2001).

10. Chiang, J. C. H., Biasutti, M. \& Battisti, D. S. Sensitivity of the Atlantic Intertropical Convergence Zone to Last Glacial Maximum boundary conditions. Paleoceanography 18, 1094 (2003).

11. Liu, Z., Brady, E. \& Lynch-Steiglitz, J. Global ocean response to orbital forcing in the Holocene. Paleoceanography 18, 19-20 (2003).
12. Li, T. M. \& Philander, S. G. H. One the seasonal cycle of the equatorial Atlantic Ocean. J. Clim. 10, 813-817 (1997).

13. Vellinga, M. \& Wood, R. A. Global impacts of a collapse of the Atlantic thermohaline circulation. Climatic Change 54, 251-267 (2002).

14. Chiang, J. C. H. \& Bitz, C. M. Influence of high-latitude ice cover on the marine Intertropical Convergence Zone. Clim. Dynam. 25, 477-496 (2005).

15. Kutzbach, J. E. \& Liu, Z. Response of the African monsoon to orbital forcing and ocean feedbacks in the middle Holocene. Science 278, 440-444 (1997).

16. Chiang, J. C. H., Kushnir, Y. \& Gianninni, A. Deconstructing tropical Atlantic ITCZ variability: Influence of the local cross-equatorial SST gradient and remote forcing from the equatorial Pacific. J. Geophys. Res. 107, 4004 (2002).

17. Mix, A. \& Ruddiman, W. F. Structure and timing of the last deglaciation: Oxygen isotope evidence. Quat. Sci. Rev. 4, 59-108 (1985).

18. Dekens, P., Lea, D., Pak, D. \& Spero, H. Core top calibration of $\mathrm{Mg} / \mathrm{Ca}$ in tropical foraminifera: Refining paleotemperature equations. Geochem. Geophys. Geosyst. 3, 1022 (2002).

19. Arbuszewski, J., deMenocal, P., Kaplan, A. \& Farmer, E. C. On the fidelity of shell-derived $\delta^{18} \mathrm{O}_{\text {seawater }}$ estimates. Earth Planet. Sci. Lett. 300, 185-196 (2010).

20. Schmidt, G. A. \& Mulitza, S. Global calibration of ecological models for planktic foraminifera from coretop carbonate oxygen-18. Mar. Micropaleo. 44, 125-140 (2002).

21. Waelbroeck, C. et al. Sea-level and deep water temperature changes derived from benthic formainifera isotope records. Quat. Sci. Rev. 21, 295-305 (2002).

22. Bradtmiller, L. I., Anderson, R. F., Fleisher, M. Q. \& Burckle, L. H. Opal burial in the equatorial Atlantic Ocean over the last $30 \mathrm{ka}$ : Implications for glacial-interglacial changes in the ocean silicon cycle. Paleoceanography 22, PA4216 (2007).

23. Verardo, D. J. \& McIntyre, A. Production and destruction: Control of biogenous sedimentation in the tropical Atlantic $0-300,000$ years B.P. Paleoceanography 9, 63-86 (1994).

24. Bemis, B., Spero, H., Bijma, J. \& Lea, D. Reevaluation of the oxygen isotopic composition of planktonic foraminifera: Experimental results and revised paleotemperature equations. Paleoceanography 13, 150-160 (1998).

25. LeGrande, A. N. \& Schmidt, G. A. Water isotopologues as a quantitative paleosalinity proxy. Paleoceanography 26, PA3225 (2011).

26. Legrande, A. \& Schmidt, G. Global gridded data set of the oxygen isotopic composition of seawater. Geophys. Res. Lett. 33, L12604 (2006).

27. Donohoe, A., Marshall, J., Ferreira, D. \& McGee, D. The relationship between ITCZ location and cross equatorial atmospheric heat transport; from the seasonal cycle to the Last Glacial Maximum. J. Clim. 26, 3597-3618 (2013).

28. Bracconot, P. et al. Results of PMIP2 coupled simulations of the Mid-Holocene and Last Glacial Maximum-Part 2: Feedbacks with emphasis on the location of the ITCZ and mid-and high latitudes heat budget. Clim. Past 3, 279-296 (2007)

29. Tierney, J. E., Lewis, S. C., Cook, B. I., LeGrande, A. N. \& Schmidt, G. A. Model, proxy, and isotopic perspectives on the East African Humid Period. Earth Planet. Sci. Lett. 307, 103-112 (2011).

\section{Acknowledgements}

This work was supported by NSF award OCE-0927247 and NOAA award NAO80AR4320912 awarded to P.B.dM. and a NOAA Climate and Global Change Postdoctoral Fellowship awarded to J.A.A. This project was partially supported by the LDEO Climate and Life initiative. We wish to thank R. Anderson, M. Cane, Y. Rosenthal and J. McManus for comments on the manuscript.

\section{Author contributions}

J.A.A. collected all data (except where otherwise noted), interpreted results, and prepared the manuscript and figures. P.B.dM. supervised the project, and aided in interpretation, figure making, and editing of the manuscript. C.C. obtained some of the previously unpublished G. ruber isotopic data for core VM30-40, discussed interpretation of results, and contributed to the editing of the manuscript. A.M. and L.B. discussed interpretation of results and contributed to the editing of the manuscript.

\section{Additional information}

Supplementary information is available in the online version of the paper. Reprints and permissions information is available online at www.nature.com/reprints. Correspondence and requests for materials should be addressed to J.A.A.

\section{Competing financial interests}

The authors declare no competing financial interests. 